\title{
PENGETAHUAN DAN POLA MAKAN DENGAN STATUS GIZI REMAJA DI PONDOK PESANTREN NAHDLATUL ULUM SOREANG MAROS
}

\author{
Rahmatullah Musyayyib1, Rudy Hartono', Asmaruddin Pakhri ${ }^{1}$ \\ ${ }^{1}$ Jurusan Gizi, Politeknik Kesehatan Kemenkes, Makassar.
}

\begin{abstract}
Teenagers need higher nutrients than adults in adolescents, there is an increase in physical growth and significant body development. Changes in lifestyle and eating habits of adolescents affect their intake and nutritional needs. This study aims to determine the relationship of knowledge and diet with the nutritional status of adolescents at the Nahdlatul Ulum Islamic Boarding School Soreang Maros. This research is an analytical study with cross sectional survey design. The subject in this study were adolescents at the Nahdlatul Ulum Islamic Boarding School in Soreang Maros, Maros Regency, amount to 134 people. The nutritional knowledge of the subject was obtained through interviews using a questionnaire. The subject diet was obtained through interviews using Food Frequency Quesionarrie (FFQ). Nutritional status (BMI / U) of the sample is obtained from the results of measurements of body weight and height. To find out the relationship between variables of knowledge and diet with nutritional status, chi square test was conducted using SPSS program. Data is presented in the form of frequency distribution and narrative tables. The results of the study show that subject knowledge is $73.1 \%$ good and $26.7 \%$ less. The subject diet was $53.10 \%$ less and $47.0 \%$ good. The nutritional status of the subject was 94.8 good and 5.2\% more. The results of statistical tests between variables showed no relationship between knowledge and diet and there was no relationship between knowledge and nutritional status and there was a relationship between diet and nutritional status.
\end{abstract}

Keywords : Nutrition Knowledge, Diet,Nutritional Status

\section{PENDAHULUAN}

Remaja adalah masa terjadinya perubahan yang berlangsung cepat dalam hal pertumbuhan, fisik, kognitif, dan psikososial. Batasan usia remaja menurut World Health Organization (WHO) adalah 12-24 tahun. Berdasarkan Permenkes RI No 25 tahun 2014 remaja adalah penduduk dalam rentang usia 10-18 tahun dan belum menikah.

lebih Remaja memerlukan zat gizi yang pertumbuhan fisik dan perkembangan tubuh yang signifikan. Perubahan gaya hidup dan kebiasaan makan remaja mempengaruhi sedikit banyak asupan maupun kebutuhan gizinya dapat meningkat maupun berkurang (Balitbangkes, 2014).

Berdasarkan Balitbangkes, 2013 prevalensi gizi kurus menurut Indeks Massa Tubuh (IMT) pada remaja adalah 13,1\% pada laki-laki dan $5,7 \%$ pada perempuan dan prevalensi gizi lebih pada laki-laki $6,6 \%$ dan perempuan $8,1 \%$.

Faktor-faktor yang mempengaruhi status gizi remaja adalah asupan makan, aktiftas fisik, body image, dan gender (Darmadi dan Rizka 2012). Asupan makan terkait dengan pola konsumsi pangan yang digunakan untuk mengetahui keadaan gizi suatu masyarakat (Leyna, et al 2010).

$$
\text { Keadaan gizi yang }
$$

mengkhawatirkan dapat terjadi pada kalangan anak remaja, untuk menanggulangi kecemasan tersebut salah satu tindakan yang dapat dilakukan adalah dengan melalui pengetahuan gizi.

Pengetahuan merupakan hasil dari seorang melihat, mendengar, mencium, merasa dan meraba sehingga menjadi tahu. Faktor yang mempengaruhi tingkat pengetahuan seseorang adalah tingkat pendidikan, pengalaman, informasi, lingkungan budaya dan sosial ekonomi. Di dalam diri seseorang akan terjadi proses yang berurutan yaitu Awareness (Kesadaran), dimana seseorang sadar dengan adanya stimulus. Interest (merasa tertarik) terhadap stimulus yang di dapatkan, kemudian trail yaitu seseorang mulai mencoba melakukan stimulus yang didapatkan, sehingga terjadilah perilaku (Notoadmojo, 2012).

Usia remaja 10-18 tahun merupakan periode rentan gizi karena berbagai sebab pertama, remaja memerlukan zat yang lebih tinggi karena peningkatan pertumbuhan fisik dan perkembangan yang drastis itu. Kedua perubahan gaya hidup dan kebiasaan makan remaja mempengaruhi baik asupan maupun kebutuhan gizinya. Ketiga, aktif dalam olahraga (Almatsier, Soetardjo dan Soekatri 2011).

Salah satu tempat untuk melakukan pengukuran status gizi dan pola makan remaja adalah dipesantren. Pondok 
Pesantren merupakan salah satu tempat untuk mendidik agar santri-santri menjadi orang yang berakhlak mulia dan memiliki kecerdasan yang tinggi. Santri-santri yang berada dipondok pesantren merupakan anak yang dididik yang pada dasarnya sama saja merupakan sumber daya yang menjadi generasi penerus pembangunan yang perlu mendapat perhatian yang khusus terutama kesehatan dan pertumbuhannya.

Pondok Pesantren adalah lembaga pendidikan agama dan pengajaran ilmu pengetahuan yang memiliki ciri-ciri tertentu, pesantren merupakan bagian dari struktur internal pendidikan islam di Indonesia yang di senggarakan secara tradisional yang telah menjadikan islam sebagai cara hidup (Rifa'i, 2009).

Sistem pendidikan dalam pondok pesantren setidaknya dapat membantu dalam menyelesaikan permasalahan remaja seperti kenakalan remaja. Hal ini dikaitkan dimana remaja yang tinggal di pesantren lebih dapat memahami, menghayati, dan mengamalkan agama dengan baik.

Berdasarkan uraian latar belakang di atas, akan dilakukan penelitian tentang Hubungan Pengetahuan dan Pola Makan dengan Status Gizi Remaja di Pondok Pesantren Nahdlatu Ulum Soreang Maros.

\section{METODE \\ Desain, tempat, dan waktu}

Penelitian ini merupakan penelitian secara analitik dengan pendekatan survey cross sectional karena pengambilan data variabel independen dan variabel dependen dilakukan dalam waktu bersamaan. Penelitian ini dilakukan di Pondok Pesantren Nahdlatul Ulum Soreang Maros dan penelitian dilaksanakan pada bulan Februari - Juli 2017.

\section{Jumlah dan cara pengumpulan subjek}

Populasi dalam penelitian ini adalah semua anak remaja kelas 1 dan 2 Madrasah Tsanawiyah (MTS) di Pondok Pesantren Nahdlatul Ulum Soreang Maros yang berjumlah 201 orang yang memenuhi syarat untuk menjadi subjek sebanyak 134 orang. Penentuan subjek dengan menggunakan sample random dengan jumlah 201 subjek setiap kelas dengan menggunakan sampling propersional yaitu kelas 7A subjek,
7B subjek, 7C subjek, 8A subjek, 8B subjek, $8 \mathrm{C}$ subjek dan $8 \mathrm{D}$ subjek.

\section{Jenis dan cara pengumpalan data \\ Data Primer}

Data pengetahuan gizi diperoleh melalui wawancara dengan responden dengan menggunakan kuesioner. Data polamakan diperoleh dari hasil wawancara dengan menggunakan Food Frequency Quesionarrie (FFQ). Data status gizi (IMT/U) diperoleh dari hasil Antropometri berupa pengukuran berat badan dan tinggi badan Data Sekunder

Gambaran Umum Pondok Pesantren Nahdlatul Ulum Soreang Maros

\section{Pengolahan dan analisis data \\ Data pengetahuan}

Total keseluruhan kuesioner sebanyak 20 soal dalam 1 soal terdiri skor 5 dengan jawaban benar dan nilai yang salah skornya adalah nol. Dengan cara menghitung pengetahuan jumlah yang benar di bagi jumlah soal di kali $100 \%$. Jika skor lebih $>60 \%$ maka dikatakan pengetahuannya baik, sedangkan jika kurang dari $80 \%$ maka pengetahuannya dikatakan kurang.

Data pola makan

Data pola makan di hitung dengan cara memberikan skor pada setiap item frekuensi makan yang disesuaikan dengan bahan makanan yang ada di form FFQ ( $>1$ kali per hari skornya 50, 1 kali per hari skornya $25,2-5$ kali per minggu skornya 15 , 1-4 kali per bulan skornya 1 , tidak pernah atau jarang skornya nol). Kemudian jumlahkan skor setelah itu di bagi dengan jumlah sampel untuk menentukan rata-rata pola makan pada sampel. Jika lebih atau sama dengan nilai rata-rata maka dikatakan baik, jika kurang dari nilai rata-rata dikatakan kurang.

Data status gizi

Data status gizi diperoleh dengan menghitung berat badan dan tinggi badan. Cara menentukan status gizi (IMT/U) yaitu berat badan di bagi tinggi badan pangkat dua dalam meter.

Data dianalisis dengan menggunakan uji statistik untuk menguji hipotesa yaitu dengan menggunakan uji Chi square dengan nilai $p<0.05$. 


\section{HASIL}

Berdasarkan tabel 05 menunjukkan bahwa remaja di Pondok Pesantren Nahdlatul Ulum Soreang Maros Kabupaten Maros yang memiliki pengetahuan dan pola makan baik sebanyak 48 subjek $(35,8 \%)$, sedangkan yang memiliki pengetahuan baik namun pola makan kurang sebanyak 50 subjek $(37,5 \%)$. Kemudian yang memiliki pengetahuan kurang dan pola makan baik sebanyak 15 subjek (11,2\%), sedangkan yang memiliki pengetahuan dan pola makan kurang sebanyak 21 subjek $(15,7 \%)$.

Hasil analisis Chi square nilai $p=$ 0,57 hal ini menunjukkan bahwa tidak ada hubungan antara pengetahuan dan pola makan di Pondok Pesantren Nahdlatul Ulum Soreang Maros dengan nilai $p>0.05$ ini menunjukkan bahwa Ha ditolak

Berdasarkan tabel 06 menunjukkan bahwa remaja di Pondok Pesantren Nahdlatul Ulum Soreang Maros Kabupaten Maros yang memiliki pengetahuan dan status gizi normal sebanyak 92 subjek $(68,7 \%)$, sedangkan yang memiliki pengetahuan baik namun stats gizi lebih sebanyak 6 subjek (4,5\%). Kemudian yang memiliki pengetahuan kurang dan status gizi normal sebanyak 35 subjek $(26,1 \%)$, sedangkan yang memiliki pengetahuan dan status gizi lebih sebanyak 1 subjek $(0,1 \%)$.

Hasil analisis Chi square nilai $p=0,6$ hal ini menunjukkan bahwa tidak ada hubungan antara pengetahuan dan pola makan di Pondok Pesantren Nahdlatul Ulum Soreang Maros dengan nilai $p>0.05$ ini menunjukkan bahwa Ha ditolak.

Berdasarkan tabel 07 menunjukkan bahwa remaja di Pondok Pesantren Nahdlatul Ulum Soreang Maros Kabupaten Maros yang memilik pola makan dan status gizi normal sebanyak 63 subjek $(47,0 \%)$, sedangkan yang memiliki pola makan yang baik namun status gizi lebih sebanyak 0 subjek $(0,00 \%)$. Kemudian yang memiliki Pola makan kurang dan status gizi normal sebanyak 64 subjek (47,8\%), sedangkan yang memiliki pola makan dan status gizi lebih sebanyak 38 subjek (5,2\%).

Hasil analisis Chi square nilai $\mathrm{p}$ $=, 0,01$ hal ini menunjukkan bahwa ada hubungan antara pola makan dan status gizi remaja di Pondok Pesantren Nahdlatul Ulum Soreang Maros dengan nilai $p>0.05$ ini menunjukkan bahwa Ha diterima.

\section{PEMBAHASAN}

Pengetahuan Gizi Remaja

Pengetahuan gizi adalah kemampuan seseorang untuk mengingat kembali kandungan gizi makanan serta kegunaan zat gizi tersebut dalam tubuh. Tingkat pengetahuan gizi seseorang berpengaruh terhadap sikap dan perilaku dalam memilih makanan yang pada akhirnya akan berpengaruh pada keadaan seseorang. Semakain tinggi tingkat pengetahuan gizi seseorang diharapkan semakin baik pula keadaan gizinya (Khomsan, et al dalam marina 2013).

Berdasarkan hasil penelitian diketahui bahwa pengetahuan subjek yang pada umumnya baik sebanyak 98 subjek $(73,1 \%)$.

Pola Makan Remaja

Pola makan dalam hal ini ditinjau dari susunan hidangan sangat berpengaruh erat dengan status gizi mahasiswa menurut Almatsier (2009). Susunan hidangan yang baik adalah susunan menu yang terdiri atas 4 macam golongan makanan yaitu makanan pokok, lauk pauk, sayuran dan buah. Berdasarkan analisis secara ilmu gizi maka susunan hidangan ini dengan kombinasi dan jumlah yang cocok memberikann semua zat gizi yang dibutuhkan untuk mencapai derajat kesehatan yang optimal. Makanan pokok yang berperan sebagai sumber utama energi berasal dari karbohidrat, lauk sebagai sumber protein, sayuran dan buah sebagai vitamin dan mineral.

Berdasarkan hasil penelitian diketahuai bahwa pola makan santri di Pondok Pesantren Nahdlatul Ulum Soreang Maros yang kurang sebanyak 71 subjek (53,0\%).

Status Gizi Remaja

Status gizi adalah keadaan keseimbangan dalam bentuk variabel tertentu, atau perwujudan dari nutriture dalam bentuk variabel tertentu (Supariasa, dkk 2014).

Keadaan gizi dapat berupa gizi kurang, gizi baik atau normal maupun gizi lebih. Kekurangan salah satu zat gizi dapat menimbulkan konsekuensi berupa penyakit defisiensi. Bila kekurangan dalam batas marginal dapat menimbulkan gangguan yang sifatnya lebih ringan atau menurunkan kemampuan fungsional misalnya kekurang 
vitamin B1 dapat menyebabkan badan cepat merasa lelah. Kekurangan zat besi dapat menurunkan prestasi kerja dan prestasi belajar, selain turunnya daya tahan tubuh terhadap penyakit infeksi.

Faktor-faktor yang mempengaruhi status gizi menurut UNICEF (1988) antara lain, yaitu asupan makanan dan penyakit infeksi sebagai penyebab langsung. Ketahanan pangan keluarga, pola pengasuhan anak Serta pelayanan kesehatan sebagai penyebab tidak langsung. Pemberdayaan keluarga dan pemberdayaan sumber daya masyarakat merupakan pokok masalah, serta krisis ekonomi, politik dan sosial yang menjadi akar masalah (Aritonang, 2010).

Berdasarkan hasil penelitian diketahuai bahwa status gizi sampel berdasarkan Indeks Massa Tubuh (IMT) menurut umur di Pondok Pesantren Nahdltaul Ulum Soreang Maros yang normal sebanyak 127 subjek (94,8\%).

Hubungan Pengetahuan dan Pola Makan

Tingkat pengetahuan gizi seseorang berpengaruh terhadap sikap dan perilaku dalam pemilihan makanan yang pada akhirnya akan berpengaruh pada keadaan gizi individu yang bersangkutan. Semakin tinggi tingkat pengetahuan gizi seseorang diharapkan semakin baik pula keadaan gizinya. Akan tetapi, pengetahuan gizi yang dimiliki seseorang belum tentu dapat mengubah kebiasaan makannya, dimana mereka memiliki pemahaman terkait asupan gizi yang diperlukan oleh tubuh tetapi tidak mengaplikasikan pengetahuan gizi tersebut dalam kehidupan sehari-harinya (Folrence G. A, 2017).

Berdasarkan hasil penelitian yang dilakukan di Pondok Pesantren Nahdlatul Ulum Soreang Maros Kabupaten Maros menunjukkan bahwa tidak ada hubungan antara pengetahuan dan pola makan baik sebanyak 48 subjek $(35,8 \%)$, sedangkan yang memiliki pengetahuan baik namun pola makan kurang sebanyak 50 subjek $(37,5 \%)$. Kemudian yang memiliki pengetahuan kurang dan pola makan baik sebanyak 15 subjek $(11,2 \%)$, sedangkan yang memiliki pengetahuan dan pola makan kurang sebanyak 21 subjek $(15,7 \%)$ dengan nilai $p$ $=0,5$. Hasil penelitian menunjukkan bahwa tidak ada hubungan pengetahuan gizi dan pola makan.
Hal ini dapat disebabkan pengetahuan gizi yang dimiliki seseorang belum tentu dapat mengubah kebiasaan makannya, dimana mereka memiliki pemahaman terkait asupan gizi yang diperlukan oleh tubuh tetapi tidak mengaplikasikan pengetahuan gizi tersebut dalam kehidupan sehari-harinya Folrence $G$. A (2017).

Hal ini sejalan dengan penelitian yang dilakukan oleh Damayanti, dkk (2014) bahwa tidak terdapat hubungan antara pengetahuan gizi dan pola makan. Penyebab tidak adanya hubungan antara pengetahuan gizi dan pola makan dikarenakan memiliki pola makan yang meliputi jumlah, jenis dan frekuensi berada pada kategori yang tidak sesuai dengan kebutuhan gizi yang dianjurkan setiap harinya.

Berbeda dengan hasil penelitian yang dilakukan, hasil penelitian dari Florence G. A (2017) menyatakan bahwa ada hubungan yang signifikan antara pengetahuan gizi dan pola makan.

Pengetahuan gizi merupakan aspek kognitif yang menunjukkan pemahaman responden tentang ilmu gizi, jenis zat gizi serta interaksinya terhadap status gizi. Pengetahuan gizi merupakan landasan yang penting dalam menentukan konsumsi makanan (Khonsam, 2000).

Hubungan Pengetahuan dan Status Gizi

$$
\text { Pengetahuan Gizi adalah }
$$

kepandaian memilih makanan yang merupakan sumber zat-zat gizi dan kepandaian dalam memilih makanan jajanan yang baik. Pengetahuan gizi sendiri sangat perlu dimiliki oleh setiap orang atau masyarakat karena kesalahan dalam memilih makanan akan berdampak buruk pada kesehatan.

Kecenderungan seseorang untuk memiliki motivasi perilaku kesehatan yang baik dipengaruhi oleh tingkat pengetahuan, sikap dan keterampilannya (Emilia, 2008). Apabila penerimaan perilaku didasari oleh pengetahuan, kesadaran dan sikap dan positif maka perilaku tersebut akan berlangsung lama (Notoatmodjo, 2007). Oleh karena itu apabila mempunyai pengetahuan gizi baik diharapkan mempunyai status gizi baik.

$$
\text { Berdasarkan hasil penelitian }
$$
menunjukkan bahwa remaja di Pondok 
Pesantren Nahdlatul Ulum Soreang Maros Kabupaten Maros yang yang memiliki pengetahuan dan status gizi normal sebanyak 92 subjek $(68,7 \%)$, sedangkan yang memiliki pengetahuan baik namun stats gizi lebih sebanyak 6 subjek (4,5\%). Kemudian yang memiliki pengetahuan kurang dan status gizi normal sebanyak 35 subjek $(26,1 \%)$, sedangkan yang memiliki pengetahuan dan status gizi lebih sebanyak 1 subjek $(0,1 \%)$ dengan hasil nilai $p=0,6$. Hasil penelitian menunjukkan bahwa tidak ada hubungan pengetahuan dan status gizi. $\mathrm{Hal}$ ini sejalan dengan penelitian yang dilakukan oleh Hendrayati, Salmiah, \& Suriani R, (2010), yang dilakukan pada siswa SMPN 4 Tompobulu Kabupaten Bantaeng bahwa tidak terdapat hubungan yang signifikan antara hubungan pengetahuan gizi dan status gizi.

Penyebab tidak adanya hubungan antara pengetahuan dengan status gizi adalah karena pengetahuan adalah memberi pengaruh secara tidak langsung terhadap status gizi, tetapi pengetahuan gizi adalah pokok masalah dari permasalahan gizi. Sedangakan penyebab langsung dari masalah gizi adalah asupan gizi dan penyakit infeksi. Di antara penyebab langsung dan pokok masalah ada penyebab tidak langsung yaitu persediaan makanan di rumah, perawatan anak dan ibu hamil dan pelayanan kesehatan. Pokok masalah selain dari pengetahuan juga terdiri dari pendidikan, kemiskinan dan keterampilan dimana akar masalahnya adalah krisis ekonomi langsung (Supariasa, dkk 2014).

Penelitian ini mendukung peneltian terdahulu yaitu penelitian yang dilakukan oleh Kristianti N, (2009) yang hasil penelitian menunjukan bahwa tidak adanya hubungan antara pengetahuan gizi dengan status gizi ini dikarenakan status gizi tidak hanya dipengaruhi oleh faktor tidak langsung tetapi dipengaruhi oleh faktor langsung seperti infeksi dan konsumsi pangan.

Berbeda dengan hasil penelitian yang dilakukan, hasil penelitian dari Florence G. A (2017) menyatakan bahwa ada hubungan yang bermakna antara pengetahuan gizi dengan status gizi. Hubungan antara pengetahuan dengan status gizi terlihat bahwa semakin rendah pengetahuan mahasiswa tentang gizi akan semakin besar kemungkinan untuk memiliki status gizi kurus atau gemuk.

Sediaoetama (2000) berpendapat bahwa kesalahan dalam memilih makanan dan kurang cukupnya pengetahuan tentang gizi akan mengakibatkan timbulnya masalah gizi yang akhirnya mempengaruhi status gizi. Status gizi yang baik hanya dapat tercapai dengan pola makan yang baik, yaitu pola makan yang didasarkan atas prinsip menu seimbang, alami dan sehat.

Pendidikan mempengaruhi pengetahuan yaitu, dengan memberikan intervensi pendidikan gizi dua minggu sekali dengan alat bantu booklet secara langsung pada siswa, didukung dengan pendidikan gizi pada guru kelas dan orangtua dalam hal ini ibu akan meningkatkan pengetahuan. Pendapat yang sama juga dinyatakan oleh Talahatu (2006) yaitu, terdapat hubungan positif nyata antara pengetahuan gizi dan kesehatan dengan tingkat pendidikan formal. Makin tinggi tingkat pengetahuan, pendidikan, keterampilan makin baik tingkat ketahanan pangan keluarga, makin baik pola pengasuhan maka akan banyak keluarga yang memanfaatkan pelayanan kesehatan, sehingga diharapkan status gizi baik (Zulaekah, 2011).

Hubungan Pola Makan dan Status Gizi

Ketersediaan makanan dalam suatu rumah tangga, masyarakat bahkan negara sangat berlebihan jumlahnya tapi pembagian kepada masyarakat yang tidak menyeluruh membuat sebagian masyarakat tidak memperolehnya. Status gizi merupakan suatu keseimbangan asupan seseorang yang merupakan suatu indikator baik-tidaknya ketersediaan makanan seharihari. Status gizi yang baik sangatlah diperlukan agar derajat kesehatan, kebugaran, dan pertumbuhan seseorang dalam tetap dipertahankan (Aritonang, 2011).

Asupan zat gizi kurang dengan yang status gizi normal dapat dipengaruhi oleh pola makan yang tidak baik, terbukti ada sebagai mahasiswa yang tinggal dikoskosan memiliki frekuensi makan dan susunan hidagan yang kurang. Disamping itu kelemahan dan metode recall 24 jam adalah tidak dapat menggambarkan status gizi sekarang, bisa saja status gizi mahasiswa terdahulu baik namun pada saat melakukan recall asupan makanan yang 
dikonsumsi kurang. Penyebab lainnya adalah mahasiswa yang tinggal dikos-kosan lebih memilih makanan yang siap saji yang miskin dengan akan zat gizi. Menurut Khosman (2004) bahwa pemilihan makanan yang kaum remaja sudah tidak lagi didasarkan pada kandungan zat gizi tetapi sekedar bersosialisasi untuk kesenangan, dan supaya tidak kehilangan status. Disamping itu kekawatiran untuk menjadi gemuk telah memaksa mereka untuk mengurangi jumlah pangan yang seharusnya dikonsumsi (Arisman, 2004).

Berdasarkan hasil penelitian bahwa remaja di Pondok Pesantren Nahdlatul Ulum Soreang Maros Kabupaten Maros yang memilik pola makan dan status gizi normal sebanyak 63 subjek (47,0\%), sedangkan yang memiliki pola makan yang baik namun status gizi lebih sebanyak 0 subjek $(0,00 \%)$. Kemudian yang memiliki Pola makan kurang dan status gizi normal sebanyak 64 subjek $(47,8 \%)$, sedangkan yang memiliki pola makan dan status gizi lebih sebanyak 38 subjek $(5,2 \%)$ dengan nilai $p=0,01$ Hasil penelitian menunjukkan bahwa berdasarkan analisis statistik dengan menggunakan uji Chi square didapat hasil, ada hubungan antara pola makan dengan status gizi nilai $p$ $=0,01$

Penelitian ini sejalan dengan penelitian yang dilakukan oleh Gouado (2010) di Kamerun yang menyatakan bahwa ada hubungan yang signifikan antara pola makan dengan status gizi. Penelitian lain di Amerika yang menyatakan ada hubungan antara pola konsumsi dengan status gizi pada siswa remaja dengan total sampel sebanyak 48 responden. Pengujian data menggunakan analisis Chi Square dan Spearman (Tombs, 2009).

Pada dasarnya status gizi seseorang ditentukan berdasarkan asupan gizi dan kemampuan tubuh dalam menggunakan zat-zat gizi tersebut. Pola makan remaja sangat dipengaruhi oleh lingkungan sekitar. Remaja lebih menyukai makanan dengan kandungan natrium dan lemak yang tinggi tetapi rendah vitamin dan mineral.

Kebiasaan makan yang sering terlihat pada remaja antara lain makan cemilan, melewatkan waktu makan terutama sarapan pagi, waktu makan tidak teratur, sering makan fast food, jarang mengkonsumsi sayuran, buah dan ataupun produk peternakan serta pengontrolan berat badan yang salah pada remaja putri. Hal tersebut dapat mengakibatkan asupan makanan tidak sesuai kebutuhan dan gizi seimbang dengan akibatnya gizi kurang atau lebih (Irianto, 2014).

Tidak adanya hubungan antara pola makan dan status gizi disebabkan karena status gizi bersifat multifaktorial, pola makan hanya merupakan salah satu faktor dari sekian banyak faktor, status gizi seseorang bukan hanya disebabkan oleh pola makanya tapi merupakan interaksi dengan faktorfaktor lain yang dalam penelitian ini tidak dijadikan variabel penelitian seperti asupan makan, penyakit infeksi yang merupakan penyebab langsung yang mempengaruhi status gizi.

\section{KESIMPULAN}

Berdasarkan hasil penelitian diketahui bahwa pengetahuan yang pada umumnya baik sebanyak 98 subjek $(73,1 \%)$. Berdasarkan hasil penelitian diketahui bahwa pola makan remaja di Pondok Pesantren Nahdlatul Ulum Soreang Maros yang kurang sebanyak 71 subjek $(53,0 \%)$. Berdasarkan hasil penelitian diketahui bahwa status gizi sampel berdasarkan Indeks Massa Tubuh (IMT) menurut umur di Pondok Pesantren Nahdltaul Ulum Soreang Maros yang normal sebanyak 127 subjek $(94,8 \%)$. Tidak ada hubungan antara pengetahuan dan pola makan dan tidak ada hubungan antara pengetahuan dan status gizi di Pondok Pesantren Nahdlatul Ulum Soreang Maros. Ada hubungan pola makan dan status gizi di Pondok Pesantren Nahdlatul Ulum Soreang Maros.

\section{SARAN}

Para peneliti yang lain, dapat melakukan penelitian lanjutan dengan menambah variabel yang lain, misalnya dengan meneliti asupan khususnya energi dan protein, pola/kebiasaan makan dengan kejadian status gizi. Bagi institusi pendidikan, perlu adanya upaya peningkatan pengetahuan gizi dengan upaya menambah fasilitas seperti bukubuku seputar perkembangan informasi gizi dan kesehatan. Bagi remaja, perlu adanya perbaikan dalam konsumsi makan baik 
kualitas maupun kuantitas serta aneka ragam makanan seperti dalam pesantren. Bagi institusi kesehatan, perlu adanya upaya peningkatan kerja sama dengan

\section{DAFTAR PUSTAKA}

Almatsier, S. (2009). Prinsip Dasar Ilmu Gizi. Jakarta : Penerbit PT Gramedia Pustaka Utama.

Almatsier, S., Soetardjo, S. dan Soekatri, M. (2011). Gizi Seimbang dalam Daur Kehidupan. Jakarta; PT. Gramedia Pustaka Utama.

Arisman MB, (2004). Gizi dan Daur Kehidupan, Jakarta; Buku Kedokteran EGC.

Aritonang H. (2010). Menilai Status Gizi untuk Mencapai Sehat Optimal. Yogyakarta; Leutika.

Balitbangkes, (2013). Laporan Riset Kesehatan Dasar 2013. Jakarta; Kementrian Republik Indonesia.

Balitbangkes, (2014). Pusat Data dan Informasi Kesehatan RI (INFODATIN). Jakarta; Sexual Girl Health.

Damayanti, dkk (2014). Hubungan pengetahuan gizi pada remaja putrid dengan kejadian anemia di SMP Negri 2 kotapinang. Skripsi; Universitas Sumatera Utara.

Darmadi \& Rizka, (2012). Analisis Regresi Logistik Untuk Faktor- Faktor Yang Mempengaruhi Status Gizi Remaja. Artikel Penelitian. RSUD Z.A. Pagar Alam Way Kanan Lampung.

Dewi, S.R. (2013). Hubungan antara Pengetahuan Gizi, Sikap Terhadap Gizi, dan Pola Konsumsi Siswa Kelas XII Program Keahlian Jasa pihak sekolah dalam usaha penanggulangan gizi kurang dengan melakukan pemantauan status gizi dan pemeriksaan kesehatan secara berkala.

Boga di SMKN 6 Yogyakarta. Skripsi; Universitas Negeri

Emilia O, (2008). Promosi Kesehatan dalam Lingkup Kesehatan Reproduksi Yogjakarta. Pustaka Cendikia Press.

Florence G. A, (2017). Hubungan Pengetahuan Gizi dan Pola Konsumsi dengan Status Gizi Pada Mahasiswa TPB Sekolah Bisnis dan Manajemen Institut Teknologi Bandung. Skripsi; Program Studi Teknologi Pangan Fakultas Teknik Universitas Pasudan Bandung.

Hendrayati, Salmiah, \& Suriani R, (2010). Pengetahuan Gizi, Pola Makan, dan Status Gizi Siswa SMP Negeri 4 Tompobulu Kabupaten Bantaeng . Media Gizi Pangan, IX (1), JanuariJuni 2010.

Irianto K, (2014). Gizi Seimbang dalam Kesehatan Reproduksi. Alfabeta. Bandung

Khosman A, (2000). Teknik Pengukuran Pengetahuan Gizi. Institut Pertanian Bogor. Bogor

Kristianti, N, dkk (2009). Hubungan Pengetahuan Gizi Dan Frekuensi Konsumsi Fast Food dengan Status Gizi Siswa SMA Negeri 4 Surakarta. jurnal kesehatan Vol 2, No 1. Juni 2009 hal 39-47.

Leyna, G.H., Mmbaga, E.J., Mnyika, K.G., Hussain, A., dan Klepp, K.I. (2010). Food Insecurity is Associated with Food Consumption Patterns and Anthropometric Measures but not Serum Micronutrient Levels in Adults in Rural Tanzania. Public 
Health Nutrition. Tanzania 13(9): 1438- 1444.

Marina, (2013). Hubungan Pengetahuan Gizi dengan Kebiasaan Makan Peserta Didik Kelas XI Jasa Boga SMK N 6 Yogyakarta. Skripsi; DIY Yogyakarta.

Notoatmodjo, S. (2007). Promosi Kesehatan dan Ilmu Prilaku. PT. Rineka Cipta. Jakarta

Notoatmojo. (2012). Metodologi Penelitian Kesehatan. Jakarta: Penerbit Rinika Cipta..

Rifa'l, (2009). Biografi singkat Wahid Hasyim. Yogyakarta; Arruz Media

Sediaoetama A. D, (2000). IImu Gizi Untuk Mahasiswa dan Profi Jilid 1. Dian rakyat. Jakarta..

Sirajuddin, Mustamin, Nadimin, Suriani Rauf, (2015). Survei Konsumsi
Pangan. Editor; Etika Rezkina, S.Gz.Jakarta; Buku Kedokteran EGC.

Supriasa, (2014). Penilaian Status Gizi. Jakarta; Penerbit Buku Kedokteran EGC.

Talahalatu A.H, (2006). Kajian Indeks Massa Tubuh (IMT) dan Pertambahan Berat Badan Ibu Hamil Serta Hubungannya dengan Tumbuh Kembang Bayi Lahir di Kota Ambon. Diakses 16 Juli 2018.

Tombs, A.M, (2009). Eating Patterns And Physical Actifity Levels Of Adolescents With Differing Weight Stattus. Thesis. D'Youville College. USA.

Zulaekah S, (2011). Efektivitas Pendidikan Gizi dengan Media Booklet terhadap Pengetahuan Gizi Anak SD. (diakses $19 \quad$ Juli 2018 http://journal.unnes.ac.id/index.php/ kemas). 
Tabel. 01

Distirbusi Umur Subjek di Pondok Pesantren Nahdlatul Ulum Soreang Maros

\begin{tabular}{ccc}
\hline Umur & $\mathrm{n}$ & $\%$ \\
\hline 13 & 58 & 43,3 \\
14 & 74 & 55,2 \\
15 & 2 & 1,5 \\
\hline Total & 134 & 100,0
\end{tabular}

Sumber : Data Primer, 2018.

Tabel. 02

Distribusi Pengetahuan Subjek di Pondok Pesantren Nahdlatul Ulum Soreang Maros Kabupaten Maros Kabupaten Maros

\begin{tabular}{ccc}
\hline Pengetahuan & $\mathrm{n}$ & $\%$ \\
\hline Baik & 98 & 73,1 \\
Kurang & 35 & 26,7 \\
\hline Total & 134 & 100,0
\end{tabular}

Sumber : Data Primer, 2018.

Tabel. 03

Distribusi Subjek Pola Makan Sampel di Pondok Pesantren Nahdlatul Ulum Soreang Maros

Kabupaten Maros

\begin{tabular}{ccc}
\hline Pola Makan & $\mathrm{n}$ & $\%$ \\
\hline Kurang & 71 & 53,0 \\
Baik & 63 & 47,0 \\
\hline Total & 134 & 100,0
\end{tabular}

Sumber : Data Primer, 2018.

Tabel. 04

Distribusi Status Gizi Subjek Menurut IMT/U di Pondok Pesantren Nahdlatul Ulum Soreang Maros

Kabupaten Maros

\begin{tabular}{ccc}
\hline Status Gizi & $\mathrm{n}$ & $\%$ \\
\hline Normal & 127 & 94,8 \\
Lebih & 7 & 5,2 \\
\hline Total & 134 & 100,0
\end{tabular}

Sumber : Data Primer, 2018. 
Tabel. 05

Hubungan Pengetahuan dan Pola Makan Remaja Di Pondok Pesantren Nahdlatul Ulum Soreang Maros

Kabupaten Maros

\begin{tabular}{|c|c|c|c|c|c|c|c|c|}
\hline \multirow[t]{3}{*}{ Pengetahuan } & \multicolumn{4}{|c|}{ Pola Makan } & \multirow{2}{*}{\multicolumn{2}{|c|}{ Total }} & \multirow{3}{*}{$P$} & \multirow{3}{*}{$\mathrm{X} 2$} \\
\hline & \multirow{2}{*}{$\begin{array}{c}\text { Baik } \\
\mathrm{n}\end{array}$} & \multicolumn{3}{|c|}{ Kurang } & & & & \\
\hline & & $\%$ & $\mathrm{n}$ & $\%$ & $\mathrm{n}$ & $\%$ & & \\
\hline Baik & 48 & 35,8 & 50 & 37,5 & 98 & 73,1 & & \\
\hline Kurang & 15 & 11,2 & 21 & 15,7 & 36 & 26,9 & 0,5 & 0,31 \\
\hline Total & 63 & 47,0 & 71 & 53,0 & 134 & 100 & & \\
\hline
\end{tabular}

Sumber : Data Primer, 2018.

Tabel. 06

Hubungan Pengetahuan dan Status Gizi Remaja di Pondok Pesantren Nahdlatul Ulum Soreang Maros

Kabupaten Maros

\begin{tabular}{|c|c|c|c|c|c|c|c|c|}
\hline \multirow[t]{3}{*}{ Pengetahuan } & \multicolumn{4}{|c|}{ Satus Gizi } & \multirow{2}{*}{\multicolumn{2}{|c|}{ Total }} & \multirow{3}{*}{$P$} & \multirow{3}{*}{$\mathrm{X} 2$} \\
\hline & \multirow{2}{*}{$\begin{array}{c}\text { Normal } \\
\mathrm{n}\end{array}$} & & \multicolumn{2}{|c|}{ Lebih } & & & & \\
\hline & & $\%$ & $\mathrm{n}$ & $\%$ & $\mathrm{n}$ & $\%$ & & \\
\hline Baik & 92 & 68,7 & 6 & 4,5 & 98 & 73,1 & & \\
\hline Kurang & 35 & 26,1 & 1 & 0,7 & 36 & 26,9 & 0.6 & 0,11 \\
\hline Total & 62 & 46,3 & 72 & 53,7 & 134 & 100 & & \\
\hline
\end{tabular}

Sumber : Data Primer, 2018.

Tabel. 07

Hubungan Pola Makan dan Status Gizi Remaja di Pondok Pesantren Nahdlatul Ulum Soreang Maros

Kabupaten Maros

\begin{tabular}{|c|c|c|c|c|c|c|c|c|}
\hline \multirow[t]{3}{*}{ Pola Makan } & \multicolumn{4}{|c|}{ Satus Gizi } & \multirow{2}{*}{\multicolumn{2}{|c|}{ Total }} & \multirow{3}{*}{$P$} & \multirow{3}{*}{$\mathrm{X} 2$} \\
\hline & \multirow{2}{*}{$\begin{array}{c}\text { Normal } \\
\mathrm{n}\end{array}$} & & \multicolumn{2}{|c|}{ Lebih } & & & & \\
\hline & & $\%$ & $\mathrm{n}$ & $\%$ & $n$ & $\%$ & & \\
\hline Baik & 63 & 47,0 & 0 & 0,0 & 63 & 47 & & \\
\hline Kurang & 64 & 47,8 & 7 & 5,2 & 71 & 53 & 0,01 & 4,7 \\
\hline Total & 127 & 94,8 & 7 & 5,2 & 134 & 100 & & \\
\hline
\end{tabular}

Sumber : Data Primer, 2018. 